\title{
WIREs Climate Change 2018: an editorial
}

\author{
Mike Hulme, Editor-in-Chief, University of Cambridge
}

18 October 2017

It was just over 10 years ago in 2007 that I was approached by John Wiley \& Sons inquiring as to my interest in taking the lead editor's role in shaping a new interdisciplinary review journal covering climate change. After two years of planning, the first issue of WIRES Climate Change was published in February 2010 and this issue marks the beginning of Volume 9. As the journal approaches its tenth anniversary I reflect here on recent developments in the journal and further afield in climate change publishing and research. This editorial should therefore be seen as following in the line of my earlier editorials (Hulme, 2010; 2014).

This editorial also signals my recent move from King's College London to the University of Cambridge, in both cases holding positions in departments of geography. For those who have heard me speak on climate change you will know that I make no apologies for my belief in the primacy of 'geography' as a disciplinary space in which the many dimensions of climate change as a socio-natural phenomenon can best be studied and taught. Geography, at least in the UK, knows no intellectual boundaries and this is reflected in my approach to curating the content of WIREs Climate Change. The scope of climate change reviews published here very deliberately covers humanities disciplines and interpretative social sciences, as well as the social sciences more broadly, and environmental geography, the natural sciences and economics. Over the last four years we have published an average of 50 review articles per year, with a growing number of reviews looking at aspects of climate engineering (e.g. Linner \& Wibeck, 2015; Irvine et al., 2016) and from Chinese authors (e.g. Fan, 2015; Liu et al., 2017; Zhang, 2017). We have also published reviews from environmental theologians (e.g. Clingerman and O'Brien, 2017), eco-critics (e.g. Boulton, 2016) and visual arts scholars (e.g. Nurmis, 2016).

There have been a few changes to the Executive Editorial Board of the journal since 2014 and these are reflected in Table 1. Lisa Dilling has taken over the domain of vulnerability and adaptation to climate change from Maria Carmen Lemos, Anita Engels the domain of the social status of climate change knowledge from Myanna Lahsen, Karin Bäckstrand the domain of climate policy and governance from Matt Hoffman and Jessica Trancik the domain of the carbon economy and climate mitigation from Kelly Gallagher. Of the 14 executive editors, eight are from Europe, four from the USA and one each from South America and southeast Asia. Women outnumber men, eight to six. It is also worth pointing out two related WIREs titles: WIREs Energy and Environment which started publishing in 2012 and WIREs Water publishing since 2014. Also publishing review articles, these two journals publish some inter-disciplinary material which intersects with the content of WIREs Climate Change in the areas of climate mitigation and climate impacts respectively. 


\section{The Continued Emergence of New 'Climat' Journals}

In my original 2010 editorial on the launch of WIREs Climate Change (Hulme, 2010), I listed the 14 academic journals which were then publishing using the string 'climat' in their title. WIREs Climate Change was the 15th such journal to launch in a history dating back to 1948 with the publication of Theoretical and Applied Climatology. By 2014 this number had doubled to 27 (Hulme, 2014). Since then, another 11 'climat' journals need adding to the list, including four that I had missed back in 2014-Environmental and Climate Technologies (2009); Climate Law (2010); Advances in Climate Change Research (2010); British Journal of Environment and Climate Change (2011). This brings the total to 38, nearly three times the number when WIREs Climate Change was launched in 2010 (see Table 2).

These 11 additional 'climat' journals reflect the continued salience of climate in everyday public and political life around the world, as well as the evolving scope of climate research and academic scholarship. New journals have launched covering climate and law, climate and ecology (e.g. Climate Change Responses) and climate services, as well as a clutch of new wide-ranging multidisciplinary journals (e.g. Current Climate Change Reports). The disciplinary scope or boundaries of some of these new journals is not always clear (e.g. British Journal of Environment and Climate Change), but the topic of climate (as captured through the string 'climat') continues to be a popular attractor around which new journals emerge and publishers commit'. These new titles are nearly all fully open-access, reflecting the changing academic journal publishing environment, with just a couple offering mixedmode publishing-i.e., subscription access plus an open-access 'gold' option. Predatory journals remain a serious threat to the integrity of the scientific enterprise (e.g. Moher et al., 2017) and care should always be exercised by prospective authors in establishing the integrity of the practices and credentials of journals in which they have not previously published.

Table 2 also shows journal impact factors for 2016 using the established Web of Science JCR scores, but also the new Scopus CiteScore Index. WIREs Climate Change has established itself as one of the top handful of 'climat' journals for average citations, being placed second in JCR lists and third for CiteScore index. All WIREs articles now also have an Altmetric score which is a new measure of article salience according to a portfolio of social media platforms (Thelwell et al., 2013). Altmetric scores are a way of capturing the amount of rapid attention an article is getting on social media, but they remain unconvincing as a measure of serious engagement with, assimilation of or reflection on new ideas. For example, recent work by Robinson-Garcia et al. (2017:1) showed that "much human tweeting [is] almost entirely mechanical and devoid of original thought". In their case study of the field of dentistry they found that less than $10 \%$ of tweets about journal articles reveal any form of active engagement with the content of the article. Despite the rise of Altmetrics, traditional citation metrics of individual articles continue to be widely used as a measure of academic impact. Table 3 lists the ten most-cited WIREs Climate Change articles, although these counts are not normalised for different citation practices pertaining in the different disciplinary fields covered by the journal. There is now widespread agreement that using 
journal impact factors as a proxy for the quality or relevance of individual articles (or authors) is inappropriate (Callaway, 2016). Nevertheless, journal impact factors continue to have comparative value as an index of the visibility, quality and impact of a given journal as a publishing platform for new research and scholarship.

The readership of WIREs Climate Change continues to grow. In 2016, 3,424 institutions offered access to the latest content, via either a Wiley License or a traditional (title-by-title) subscription. Philanthropic initiatives extend low-cost or free access to current content to a further 4,053 developing world institutions, so the journal is available to read in nearly 7,500 institutions world-wide (see Figure 1). WIREs Climate Change offers gold-access for authors if they wish and have the funds to pay. Around 15\% of articles now appearing in WIREs Climate Change are fully open-access.

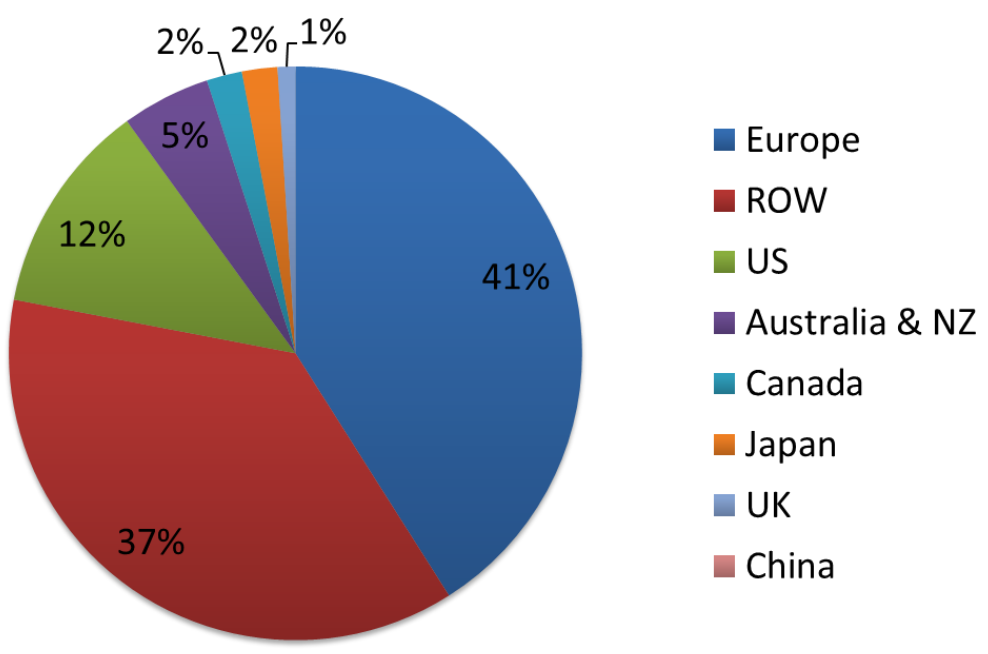

Figure 1: Institutional access to WIREs Climate Change by country and region (2016).

\section{What Makes a Good Review Article?}

WIREs Climate Change is explicitly a 'review' journal, as are all 12 WIREs titles from Wiley. That is, it publishes synthesised reviews of published work rather than new empirical studies or findings. But what constitutes a review article? One definition, adapted from Meyer (2009) would be:

A critical, constructive, stand-alone analysis of the literature in a specific field through summary, classification, analysis, comparison. It should rely upon previously published literature and/or data.

Typically, review articles summarise, organise, synthesise and evaluate existing literature, identifying patterns and trends, bringing forward new insights or arguments and identifying deficiencies and opportunities for further work (Pautasso, 2009). The primary audiences for review articles, and this is true of WIREs Climate Change, would be experts in specific fields of study seeking introductions in adjacent/relevant fields, students or novice researchers and those working in policy advice and/or decision-making. A good example of the latter is 
the WIREs review of robust decision-making by Weaver et al. (2014), an article which has been widely cited and used in climate adaptation policy design and implementation.

There are a number of key principles involved in writing a good review. First, emphasise what is well known and what is less well known and also identify where there is ignorance or gaps in understanding. Susi Moser's review of climate change communication (Moser, 2010) is an exemplar of this principle. Second, is to offer clear and transparent criteria for bounding the issue/field being reviewed and how relevant literature is selected. The WIRES review by Linner and Wibeck (2015) nicely operationalises this principle. Third, is to be critical, to pass judgement on a field of published literature or to develop an argument. Many WIREs Climate Change reviews are critical in this sense, whilst our shorter-form Opinion Articles allow authors to offer informed personal opinion (e.g. Mazzocchi \& Pasini, 2017).

Review articles can also be categorised by either methodology or objective (Meyer, 2009). Methodologically, there is a difference between narrative, systematic and best-evidence reviews. In narrative reviews selected studies are compared and summarised on the basis of the author's experience and according to existing theories and models. Interpretation is usually qualitative rather than quantitative. Head et al. (2014) in their survey of literature on climate change and Australia offer an example of a narrative review. In a systematic review findings from many disparate studies are synthesised in a (semi-)formal manner, possibly through a meta-analysis of a defined corpus of work. The review of the concept of 'co-production' in climate research by Bremer and Meisch (2017) offers a good example of this. Third, in a best evidence review, where reviewers focus on only carefully and transparently selected studies (e.g. see the review by Hewitson et al., 2017).

Categorising by objective can suggest four types of review articles. A status quo review presents the most current research for a given topic/field (e.g. Tschakert et al., 2017, on loss and damage). A historical review surveys and summarises the development of a specific field of research over time (e.g. Lamb \& Steinberger, 2017, on well-being). An issue review investigates a specific issue in a field of research (e.g. maybe a point of disagreement amongst experts or a particularly important question). Weber (2010) offers an example of this in relation to the question of what shapes perceptions of climate change. Finally, a theory/model review introduces and applies an existing theory/model to a new field, as done by Rosenschöld et al. (2014) with regards to new institutionalism applied to the governance of climate change.

Given that the content of WIREs Climate Change crosses many different disciplines it is necessary to be flexible with regard to how these principles and categories of 'review articles' are applied. What works as a review in oceanography may not work in climate ethics or in eco-criticism for example. Similarly, drawing hard and fast lines between Overviews, Advanced Reviews, Focus Articles and Opinion Articles-our four article styles--is often impossible and requires judgement and interpretative latitude. The central principle that holds, however, is that the content of WIREs Climate Change articles will always rely very heavily upon published data and literature, albeit data and literature skilfully identified, reviewed and communicated by our authors. These articles are original in the sense of their 
synthesis, interpretation and provocation, rather than in terms of simply introducing new observations, experiments or arguments to the scholarly world. For the latter, other journals outlets should be sought.

\section{Looking Ahead}

WIREs Climate Change will continue to welcome approaches from prospective authors for new review topics which survey fields relating to climate change not yet addressed in the journal or which open up new inter-disciplinary perspectives. A forthcoming WIREs review of the implications of climate change for the sugar-cane industry (Linnenluecke et al., 2018) is a good example of how these two goals come together in a single review. Prospective authors may either approach a Domain Editor directly with their suggestions or else submit a proposal to the editorial office (See proposal guidelines here: http://media.wiley.com/assets/2266/18/WCC Proposal Guidelines.pdf). Our Executive Editors will also continue to be proactive in identifying new review topics and matching them with appropriately experienced researchers and scholars through extending be-spoke invitations to write for WIREs. We aim to reach an initial decision, guided by peer-review, on full invited manuscripts in under 100 days; and the period from final acceptance to online publication averages between 4 and 6 weeks.

As the Intergovernmental Panel on Climate Change (IPCC) embarks on its Sixth Assessment Report--due in 2021/22--it is worth commenting briefly on the relationship between the IPCC and WIREs Climate Change. The IPCC exerts a considerable influence, not only on the governmental negotiations of the UNFCCC, but also on the modes, institutions and practices of knowledge-making within universities and research institutes around the world (see Hughes \& Paterson, 2017). In this sense, the IPCC is a hegemon in the world of climate change research, i.e., 'having dominant influence and authority over others'. As the demands of the UNFCCC upon the IPCC become ever greater (Beck \& Mahony, 2017), it is important that there are other independent venues where inter-disciplinary reviews of climate change research and scholarship can be made visible and can circulate widely. WIREs Climate Change will continue to offer such a publishing platform without being constrained by the specific agendas or conditions under which the IPCC has to operate. As I remarked two years ago (Hulme, 2016:223),

“... there are many roles for climate research and knowledge production beyond servicing the needs of the IPCC. These include curiosity-driven research such as attempts to better understand the dynamics of the Earth system or processes of social and cultural change, inquiry and scholarship that challenge dominant assumptions about climate-society interactions and that offer alternative frames for thinking about policy interventions, and research oriented towards decision support for the large and diverse constituency of stakeholders beyond the state, as in support of climate services or city planning."

It is interesting to note that a significant number of review articles published in WIREs were cited in the IPCC's Fifth Assessment Report in 2013/14 (see Table 4), and I am sure many 
WIREs reviews will be found as useful sources of authoritative knowledge for the IPCC'S Special Report on global warming of $1.5^{\circ} \mathrm{C}$ in 2018 or for its $6^{\text {th }}$ Assessment Report in 2021/22. By design, however, the content of WIREs Climate Change is more expansive than the knowledge assessed by the IPCC. On the other hand, both enterprises are limited because of their reliance upon the (largely academic) published literature. Valuable as this knowledge is, it is increasingly the case that for the purposes of effecting change in the world some of the most important knowledge about climate and its implications for politics, cultural practices and material technologies is emerging in places outside conventional research institutions or academic publishing ventures. This may be, for example, in placebased communities, religious institutions, communities of practice, technology start-ups, professional bodies and associations, lay experts, corporations, civil society organisations. Neither the IPCC nor WIREs Climate Change are necessarily the right venues for these types of knowledge to be consolidated and made available for public sharing and scrutiny.

As a final word let me offer my thanks on behalf of the journal to the hundreds of people who have completed peer reviews of submitted WIREs Climate Change manuscripts over the past 4 years. Your dedicated work has been central to maintaining the integrity and quality of the journal.

\section{References}

Beck,S. and Mahony,M. (2017) The IPCC and the politics of anticipation Nature 7(5), 311313

Boulton,E. (2016) Climate change as a 'hyperobject': a critical review of Timothy Morton's reframing narrative WIREs Climate Change 7(5), 772-785

Bremer,S. and Meisch,S. (2017) Co-production in climate change research: reviewing different perspectives WIREs Climate Change 8(6), DOI:10.1002/wcc.482

Callaway,E. (2016) Beat it, impact factor! Publishing elite turns against controversial metric Nature 535, 210-211

Clingerman,F. and O'Brien,K.J. (2017) Is climate change a new kind of problem? The role of theology and imagination in climate ethics WIREs Climate Change 8(5), DOI: $10.1002 /$ wcc.480

Fan,K. (2015) Climate change and Chinese history: a review of trends, topics, and methods WIREs Climate Change 6(2), 225-238

Head,L., Adams,M., McGregor,H.V. and Toole,S. (2014) Climate change and Australia WIREs Climate Change 5(2), 175-197

Hewitson,B., Waagsaether,K., Wohland,J., Kloppers,K. and Kara,T. (2017) Climate information websites: an evolving landscape WIREs Climate Change 8(5), DOI: $10.1002 /$ wcc.470 
Hughes,H.R. and Paterson,M. (2017) Narrowing the climate field: the symbolic power of authors in the IPCC's assessment of mitigation Review of Policy Research 10.1111/ropr.12255

Hulme,M. (2016) $1.5^{\circ} \mathrm{C}$ and climate research after the Paris Agreement Nature Climate Change 6(3), 222-224

Hulme,M. (2010) Mapping climate change knowledge: editorial essay WIREs Climate Change 1(1), 1-7

Hulme,M. (2014) WIRES Climate Change after 4 years: an editorial essay WIREs Climate Change 5(1), 1-5

Irvine,P.J., Kravitz,B., Lawrence,M.G. and Muri,H. (2016) An overview of the Earth system science of solar geoengineering WIREs Climate Change, 7(6), 815-833

Lamb,W.F. and Steinberger,J.K. (2017) Human well-being and climate change mitigation WIREs Climate Change 8(6), DOI:10.1002/wcc.485

Linnenluecke,M.K., Nucifora,N. and Thompson,N. (2018, press) Implications of climate change for the sugarcane industry WIREs Climate Change

Linnér,B-O. and Wibeck,V. (2015) Dual high-stake emerging technologies: a review of the climate engineering research literature WIREs Climate Change 6(2), 255-268

Liu,L., Wang,P. and Wu,T. (2017) The role of nongovernmental organizations in China's climate change governance WIREs Climate Change 8(6), DOI:10.1002/wcc.483

Mazzocchi,F. and Pasini,A. (2017) Climate model pluralism beyond dynamical ensembles WIREs Climate Change 8(6), DOI:10.1002/wcc.477

Meyer,P. (2009) Guidelines for writing a review article Retrieved from: http://ueberfachlichekompetenzen.ethz.ch/dopraedi/pdfs/Mayer/guidelines review article.pdf

Moher,D., Shamsheer,L., Cobey,K. et al. (2017) Stop this waste of people, animals and money Nature 549, 23-25

Moser,S. (2010) Communicating climate change: history, challenges, processes and future directions WIREs Climate Change 1(1), 31-53

Nurmis,J. (2016) Visual climate change art 2005-2015: discourse and practice WIRES Climate Change 6(4), 501-516

Pautasso,M. (2013) Ten simple rules for writing a literature review PLOS Computational Biology 9(7), July, e1003149

Robinson-Garcia,N., Costas,R., Isett,K., Melkers,J. and Hicks,D. (2017) The unbearable emptiness of tweeting - about journal articles PLOS ONE 12(8): e0183551

Rosenschöld,J., Rozema,J.G. and Frye-Levine,L.A. (2014) Institutional inertia and climate change: a review of the new institutionalist literature WIREs Climate Change 5(5), 639-648 
Thelwall,M., Haustein,S., Larivière,V. and Sugimoto,C.R. (2013) Do altmetrics work? Twitter and ten other social web services PLOS One doi.org/10.1371/journal.pone.0064841

Tschakert,P., Barnett,J., Ellis,N., Lawrence,C., Tuana,N., New,M., Elrick-Barr,C., Pandit,R. and Pannell,D. (2017) Climate change and loss, as if people mattered: values, places, and experiences WIREs Climate Change 8(5), DOI: 10.1002/wcc.476

Weaver,C.P., Lempert,R.J., Brown,C., Hall,J.A., Revell,D. and Sarewitz,D. (2013) Improving the contribution of climate model information to decision-making: the value and demands of robust decision frameworks WIREs Climate Change 4(1), 39-60

Weber,E.U. (2010) What shapes perceptions of climate change WIREs Climate Change $1(3), 332-342$

Zhang,Z. (2017) Are China's climate commitments in a post-Paris agreement sufficiently ambitious? WIREs Climate Change 8(2), e443. doi:10.1002/wcc.443

Table 1: Present list of WIREs Climate Change executive Domain Editors and their Domain topics

\begin{tabular}{|c|c|c|}
\hline Domain Editor & Editor Affiliation & Domain Subject Area \\
\hline Karin Bäckstrand & Stockholm University, Sweden & Climate Policy and Governance \\
\hline Tim Carter & $\begin{array}{l}\text { Finnish Environment Institute, } \\
\text { Finland }\end{array}$ & $\begin{array}{l}\text { Assessing Impacts of Climate } \\
\text { Change }\end{array}$ \\
\hline Lisa Dilling & University of Colorado, USA & $\begin{array}{l}\text { Vulnerability and Adaption to } \\
\text { Climate Change }\end{array}$ \\
\hline Anita Engels & $\begin{array}{l}\text { University of Hamburg, } \\
\text { Germany }\end{array}$ & $\begin{array}{l}\text { The Social Status of Climate } \\
\text { Change Knowledge }\end{array}$ \\
\hline Stéphane Hallegatte & World Bank, Washington, USA & Climate Economics \\
\hline Matthias Heymann & Aarhus University, Denmark & $\begin{array}{l}\text { Climate, History, Society, } \\
\text { Culture }\end{array}$ \\
\hline Mike Hulme & University of Cambridge, UK & Transdisciplinary Perspectives \\
\hline Anja Karnein & $\begin{array}{l}\text { Binghampton University, New } \\
\text { York, USA }\end{array}$ & Climate, Nature, Ethics \\
\hline Louis Lebel & $\begin{array}{l}\text { Chiang Mai University, } \\
\text { Thailand }\end{array}$ & Climate and Development \\
\hline $\begin{array}{l}\text { Irene Lorenzoni \& Lorraine } \\
\text { Whitmarsh }\end{array}$ & $\begin{array}{l}\text { University of East Anglia, UK \& } \\
\text { Cardiff University, UK }\end{array}$ & $\begin{array}{l}\text { Perceptions, Behavior and } \\
\text { Communication of Climate } \\
\text { Change }\end{array}$ \\
\hline Matilde Rusticucci & $\begin{array}{l}\text { University of Buenos Aires, } \\
\text { Argentina }\end{array}$ & $\begin{array}{l}\text { Paleoclimates and Current } \\
\text { Trends }\end{array}$ \\
\hline Josef Settele & $\begin{array}{l}\text { UFZ Centre for Environmental } \\
\text { Research, Leipzig, Germany }\end{array}$ & $\begin{array}{l}\text { Climate, Ecology, and } \\
\text { Conservation }\end{array}$ \\
\hline Jessica Trancik & MIT, USA & $\begin{array}{l}\text { The Carbon Economy and } \\
\text { Climate Mitigation }\end{array}$ \\
\hline Eduardo Zorita & $\begin{array}{l}\text { Institute for Coastal Research, } \\
\text { Hamburg, Germany }\end{array}$ & Climate Models and Modelling \\
\hline
\end{tabular}


Table 2: The 38 English language academic journals currently publishing with the string 'climat' in their title ${ }^{1}$. NB. By listing a journal in this table, no judgement is being made on the quality of the editorial processes operated by that journal.

\begin{tabular}{|c|c|c|c|c|c|}
\hline & & & & \multicolumn{2}{|c|}{2016 Impact Factors } \\
\hline Year & Title & Academic Field(s) & Publisher & $\begin{array}{c}\text { Web of } \\
\text { Science JCR }\end{array}$ & $\begin{array}{l}\text { Scopus } \\
\text { CiteScore }\end{array}$ \\
\hline 1948 & $\begin{array}{l}\text { Theoretical and } \\
\text { Applied } \\
\text { Climatology }\end{array}$ & Climatology & Springer & 2.6 & 2.1 \\
\hline 1962 & $\begin{array}{l}\text { Journal of Applied } \\
\text { Meteorology and } \\
\text { Climatology }\end{array}$ & $\begin{array}{l}\text { Meteorology \& } \\
\text { climatology }\end{array}$ & $\begin{array}{l}\text { American } \\
\text { Meteorological } \\
\text { Society }\end{array}$ & 2.4 & 2.7 \\
\hline 1965 & $\begin{array}{l}\text { Paleogeography, } \\
\text { Paleoclimatology, } \\
\text { Paleoecology }\end{array}$ & $\begin{array}{l}\text { Quaternary } \\
\text { sciences }\end{array}$ & Elsevier & 2.6 & 2.6 \\
\hline 1977 & Climatic Change & Inter-disciplinary & Springer & 3.5 & 3.5 \\
\hline 1981 & $\begin{array}{l}\text { International } \\
\text { Journal of } \\
\text { Climatology }\end{array}$ & Climatology & Wiley-Blackwell & 3.8 & 3.5 \\
\hline 1986 & Climate Dynamics & $\begin{array}{l}\text { Meteorology \& } \\
\text { climatology }\end{array}$ & Springer & 4.1 & 4.0 \\
\hline 1988 & Journal of Climate & $\begin{array}{l}\text { Meteorology \& } \\
\text { climatology }\end{array}$ & $\begin{array}{l}\text { American } \\
\text { Meteorological } \\
\text { Society }\end{array}$ & 4.2 & 5.1 \\
\hline 1990 & Climate Research & $\begin{array}{l}\text { Climatology \& } \\
\text { geography }\end{array}$ & Inter-Research & 1.6 & 1.8 \\
\hline 2001 & Climate Policy & Policy sciences & Taylor \& Francis & 2.7 & 2.2 \\
\hline 2005 & $\begin{array}{l}\text { Climate of the } \\
\text { Past }\end{array}$ & Paleoclimatology & EGU & 3.5 & 4.0 \\
\hline 2007 & $\begin{array}{l}\text { Carbon and } \\
\text { Climate Law } \\
\text { Review }\end{array}$ & $\begin{array}{l}\text { Policy \& } \\
\text { regulation } \\
\text { disciplines } \\
\end{array}$ & Lexxion & $\mathrm{n} / \mathrm{a}$ & $\mathrm{n} / \mathrm{a}$ \\
\hline 2009 & $\begin{array}{l}\text { Climate and } \\
\text { Development }\end{array}$ & $\begin{array}{l}\text { Development } \\
\text { sciences }\end{array}$ & Taylor \& Francis & 2.1 & 1.7 \\
\hline 2009 & $\begin{array}{l}\text { Weather, Climate } \\
\text { and Society }\end{array}$ & Social sciences & $\begin{array}{l}\text { American } \\
\text { Meteorological } \\
\text { Society }\end{array}$ & 2.6 & 2.3 \\
\hline 2009 & $\begin{array}{l}\text { International } \\
\text { Journal of Climate } \\
\text { Change Strategies } \\
\text { \& Management }\end{array}$ & $\begin{array}{l}\text { Policy \& } \\
\text { management } \\
\text { disciplines }\end{array}$ & Emerald Group & 0.6 & 0.7 \\
\hline 2009 & $\begin{array}{l}\text { Environmental } \\
\text { and Climate } \\
\text { Technologies }\end{array}$ & Technology & De Gruyter & $\mathrm{n} / \mathrm{a}$ & 1.8 \\
\hline
\end{tabular}

\footnotetext{
${ }^{1}$ Two journals are excluded from this survey - Journal of Space Weather and Space Climate; International Journal of Indoor Air Quality and Climate - since their use of 'climat' pertains to extraterrestrial and indoor climates respectively.
} 


\begin{tabular}{|c|c|c|c|c|c|}
\hline 2010 & $\begin{array}{l}\text { WIREs Climate } \\
\text { Change }\end{array}$ & Inter-disciplinary & Wiley-Blackwell & 4.6 & 4.7 \\
\hline 2010 & $\begin{array}{l}\text { J of Water and } \\
\text { Climate Change }\end{array}$ & Water Science & IWA Publishing & 0.9 & 1.0 \\
\hline 2010 & $\begin{array}{l}\text { Climate Change } \\
\text { Economics }\end{array}$ & $\begin{array}{l}\text { Economics \& } \\
\text { policy disciplines }\end{array}$ & World Scientific & $\mathrm{n} / \mathrm{a}$ & $\mathrm{n} / \mathrm{a}$ \\
\hline 2010 & $\begin{array}{l}\text { Int J of Climate } \\
\text { Change Impacts } \\
\text { and Responses } \\
\end{array}$ & Inter-disciplinary & $\begin{array}{l}\text { Common Ground } \\
\text { Publishing }\end{array}$ & $\mathrm{n} / \mathrm{a}$ & $\mathrm{n} / \mathrm{a}$ \\
\hline 2010 & $\begin{array}{l}\text { J of Earth Sciences } \\
\text { and Climatic } \\
\text { Change }\end{array}$ & Earth sciences & $\begin{array}{l}\text { OMICS } \\
\text { International }\end{array}$ & $\mathrm{n} / \mathrm{a}$ & $\mathrm{n} / \mathrm{a}$ \\
\hline 2010 & Climate Law & Law & Brill Publishing & $\mathrm{n} / \mathrm{a}$ & 0.7 \\
\hline 2010 & $\begin{array}{l}\text { Advances in } \\
\text { Climate Change } \\
\text { Research }\end{array}$ & Multi-disciplinary & $\begin{array}{l}\text { Ke Ai (Beijing } \\
\text { Climate Centre) }\end{array}$ & $\mathrm{n} / \mathrm{a}$ & 1.2 \\
\hline 2011 & $\begin{array}{l}\text { Nature Climate } \\
\text { Change }\end{array}$ & Multi-disciplinary & Nature Group & 19.3 & 10.0 \\
\hline 2011 & $\begin{array}{l}\text { Atmospheric and } \\
\text { Climate Sciences }\end{array}$ & $\begin{array}{l}\text { Meteorology \& } \\
\text { climatology }\end{array}$ & $\begin{array}{l}\text { Scientific } \\
\text { Research }\end{array}$ & $\mathrm{n} / \mathrm{a}$ & $\mathrm{n} / \mathrm{a}$ \\
\hline 2011 & $\begin{array}{l}\text { British J of } \\
\text { Environment and } \\
\text { Climate Change }\end{array}$ & Multidisciplinary & $\begin{array}{l}\text { Science Domain } \\
\text { International }\end{array}$ & $\mathrm{n} / \mathrm{a}$ & $\mathrm{n} / \mathrm{a}$ \\
\hline 2012 & $\begin{array}{l}\text { American J of } \\
\text { Climate Change }\end{array}$ & $\begin{array}{l}\text { Physical climate } \\
\text { sciences }\end{array}$ & $\begin{array}{l}\text { Scientific } \\
\text { Research }\end{array}$ & $\mathrm{n} / \mathrm{a}$ & $\mathrm{n} / \mathrm{a}$ \\
\hline 2012 & Urban Climate & Inter-disciplinary & Elsevier & $\mathrm{n} / \mathrm{a}$ & 2.9 \\
\hline 2013 & Climate & Multi-disciplinary & MDPI & $\mathrm{n} / \mathrm{a}$ & $\mathrm{n} / \mathrm{a}$ \\
\hline 2013 & $\begin{array}{l}\text { Weather and } \\
\text { Climate Extremes }\end{array}$ & $\begin{array}{l}\text { Climatology \& } \\
\text { meteorology }\end{array}$ & Elsevier & $\mathrm{n} / \mathrm{a}$ & 2.8 \\
\hline 2013 & \begin{tabular}{|l} 
Climate Risk \\
Management
\end{tabular} & $\begin{array}{l}\text { Climatology, risk } \\
\text { analysis, decision } \\
\text { sciences }\end{array}$ & Elsevier & $\mathrm{n} / \mathrm{a}$ & 2.3 \\
\hline 2013 & \begin{tabular}{|l|} 
Journal of \\
Climatology
\end{tabular} & $\begin{array}{l}\text { Meteorology \& } \\
\text { climatology }\end{array}$ & Hindawi & $\mathrm{n} / \mathrm{a}$ & $\mathrm{n} / \mathrm{a}$ \\
\hline 2013 & $\begin{array}{l}\text { Journal of } \\
\text { Climatology and } \\
\text { Weather } \\
\text { Forecasting }\end{array}$ & $\begin{array}{l}\text { Climate \& } \\
\text { atmospheric } \\
\text { sciences }\end{array}$ & $\begin{array}{l}\text { OMICS } \\
\text { International }\end{array}$ & $\mathrm{n} / \mathrm{a}$ & $\mathrm{n} / \mathrm{a}$ \\
\hline 2013 & $\begin{array}{l}\text { Interdisciplinary } \\
\text { Climate Studies } \\
\text { (Section Platform) }\end{array}$ & $\begin{array}{l}\text { Physical climate } \\
\text { sciences }\end{array}$ & $\begin{array}{l}\text { Frontiers } \\
\text { (Switzerland) }\end{array}$ & $\mathrm{n} / \mathrm{a}$ & $\mathrm{n} / \mathrm{a}$ \\
\hline 2014 & $\begin{array}{l}\text { Climate Change } \\
\text { Responses }\end{array}$ & Ecology & BioMed Central & $\mathrm{n} / \mathrm{a}$ & $\mathrm{n} / \mathrm{a}$ \\
\hline 2015 & Climate Services & $\begin{array}{l}\text { Climate } \\
\text { information }\end{array}$ & Elsevier & $\mathrm{n} / \mathrm{a}$ & $\mathrm{n} / \mathrm{a}$ \\
\hline 2015 & $\begin{array}{l}\text { Current Climate } \\
\text { Change Reports }\end{array}$ & Multi-disciplinary & Springer & $\mathrm{n} / \mathrm{a}$ & $\mathrm{n} / \mathrm{a}$ \\
\hline 2016 & $\begin{array}{l}\text { Environmental } \\
\text { Pollution and } \\
\text { Climate Change }\end{array}$ & $\begin{array}{l}\text { Environmental } \\
\text { sciences }\end{array}$ & $\begin{array}{l}\text { OMICS } \\
\text { International }\end{array}$ & $\mathrm{n} / \mathrm{a}$ & $\mathrm{n} / \mathrm{a}$ \\
\hline
\end{tabular}




NPJ (Springer-
Nature)

\begin{tabular}{|l|l|}
\hline $\mathrm{n} / \mathrm{a}$ & $\mathrm{n} / \mathrm{a}$ \\
\hline
\end{tabular}

Table 3: The ten top-cited articles in WIREs Climate Change, since 2010 launch. Citations from Scopus, as of 11 October 2017.

\begin{tabular}{|l|c|l|l|}
\hline \multicolumn{1}{|c|}{ Review Title } & Citations & \multicolumn{1}{|c|}{ Author } & \multicolumn{1}{c|}{ Volume } \\
\hline Drought under global warming: a review & 772 & Dai & 2011, 2(1), 21pp. \\
\hline $\begin{array}{l}\text { Indices for monitoring changes in extremes } \\
\text { based on daily temperature and } \\
\text { precipitation data }\end{array}$ & 285 & Zhang et al. & $2011,2(6), 20 \mathrm{pp}$. \\
\hline $\begin{array}{l}\text { Communicating climate change: History, } \\
\text { challenges, process and future directions }\end{array}$ & 257 & Moser & $2010,1(1), 23 \mathrm{pp}$. \\
\hline $\begin{array}{l}\text { State-of-the-art with regional climate } \\
\text { models }\end{array}$ & 220 & Rummukainen & $2010,1(1), 15 \mathrm{pp}$. \\
\hline $\begin{array}{l}\text { Land use/land cover changes and climate: } \\
\text { Modeling analysis and observational } \\
\text { evidence }\end{array}$ & 204 & Pielke snr., et al. & $2011,2(6), 23 \mathrm{pp}$. \\
\hline What shapes perceptions of climate change? & 185 & Weber & $2010,1(3), 11 \mathrm{pp}$. \\
\hline $\begin{array}{l}\text { Detection and attribution of climate change: } \\
\text { A regional perspective }\end{array}$ & 155 & Stott et al. & $2010,1(2), 20 \mathrm{pp}$. \\
\hline $\begin{array}{l}\text { Institutions and policy processes: The means } \\
\text { to the ends of adaptation }\end{array}$ & 131 & Dovers \& Hezri & $2010,1(2), 20 \mathrm{pp}$. \\
\hline $\begin{array}{l}\text { Individual understandings, perceptions, and } \\
\text { engagement with climate change: Insights } \\
\text { from in-depth studies across the world }\end{array}$ & 125 & Wolf \& Moser & $2011,2(4), 23 \mathrm{pp}$. \\
\hline $\begin{array}{l}\text { A values-based approach to vulnerability and } \\
\text { adaptation to climate change }\end{array}$ & 114 & O'Brien \& Wolf & $2010,1(2), 11 \mathrm{pp}$. \\
\hline
\end{tabular}

Table 4: Number and percentage of WIREs Climate Change review articles cited in the IPCC AR5 reports (across all three Working Groups). The cut-off date for 'formally accepted' articles to qualify for AR5 was 15 March 2013 (WG1), 31 August 2013 (WG2) or 3 October 2013 (WG3).

\begin{tabular}{|c|c|c|}
\hline Published Volume & $\begin{array}{c}\text { WIREs CC articles cited in IPCC } \\
\text { AR5 }\end{array}$ & $\begin{array}{c}\text { Column 2 as a percentage of } \\
\text { total articles published in } \\
\text { WIREs Climate Change }\end{array}$ \\
\hline 2010 & 29 & 41 \\
\hline 2011 & 35 & 56 \\
\hline 2012 & 11 & 26 \\
\hline 2013 & 9 & 20 \\
\hline 2014 & 5 & 9 \\
\hline
\end{tabular}




\footnotetext{
' These 'climat' journals are far from being the only places where research on climate and climate change is published-for example, Science, Global Environmental Change, Bulletin of the American Meteorological Society, Current Anthropology, and many, many others, also publish articles on climate change. The 'climat' search filter simply offers one unambiguous way of selecting for comparison relevant journals that blatantly signal climate content through their titles.
} 